\title{
Is the Time Right for a Change in Company Reporting? Development of Company Reporting from Financial to Non-financial Information
}

\author{
Singer Klaus, Bußian Aykut, Tobias Stiegler, Christian Hell \\ The Bucharest University of Economic Studies, Bucharest, Romania
}

\begin{abstract}
Published financial statements and information on company performance include in the past only financial information and neglected non-financials. Investments decisions nowadays rely not only on pure financial information. The last developments of accounting rules and regulations and the current practice in company reporting put non-financial information and other decision useful non-GAAP measures in focus. A higher number of non-financial information could be found in actual company reports compared to prior years and document a shift in the reporting culture from disclosing only financial performance to an integrated reporting that also reports about performance of the total organisation and the contribution to society. Today, an integrated reporting that combines financials with non-financials and as the standard report of companies is not achieved. One step to an integrated reporting is the EU Accounts Modernisation Directive 2003/51/EC which integrated non-financial key performance indicators (KPIs) in the obligatory reporting for companies. Another step that fosters the development of companies reporting is rooted on the EU Directive 2014/95/EU (CSR directive). The directive includes rules to make non-financial information obligatory and more harmonized in published company reports. The disclosing of non-financial information, like sustainability and social responsibility, is now obligatory, harmonized and regulated in the EU.
\end{abstract}

Keywords: corporate reporting, CSR, key performance indicators, integrated reporting

\section{Introduction}

The objective of this research report is to give an overview of the development of company reporting from financial to non-financial information. The research also will give an overview of the new EU CSR directive and possible non-financial KPIs to be used to fulfil the information need of stakeholders. Published consolidated financial statements and management reports lacked in the past information in respect to non-financials, sustainability or social responsibility. Large listed companies were the first mover and included in public available reports selected information regarding sustainability or CSR (DANONE, 2015). It is common practice separating financial reporting from non-financial reporting (DANONE, 2015). Financial

Singer Klaus, Ph.D. student, Department of Business, Consumer Sciences and Quality Management, The Bucharest University of Economic Studies. Email: Klaus.Singer@mazars.de.

Bußian Aykut, Ph.D. student, Department of Business, Consumer Sciences and Quality Management, The Bucharest University of Economic Studies.

Tobias Stiegler, Ph.D. student, Department of Business, Consumer Sciences and Quality Management, The Bucharest University of Economic Studies.

Christian Hell, Ph.D. student, Department of Business, Consumer Sciences and Quality Management, The Bucharest University of Economic Studies. 
statements are much more regulated and have the obligation to be audited, while sustainability reports are voluntary and more flexible in content, layout, and disclosure requirements (Ahern, 2016). Non-financial reports are getting more attention by stakeholders. Reports on CSR and other additional reporting can create value for undertakings, such as an increase in shareholder confidence or increased attractiveness for employees and are a clear message to all stakeholders about the overall results that were delivered by the company (Ahern, 2016). Overall, the reporting from companies to stakeholders is developing beyond reporting only on financial results (PricewaterhouseCoopers, 2012a).

The information needs of investors and other stakeholders by external reporting of companies have changed, in particular, due to the increasing importance of sustainability aspects for the success of companies (PricewaterhouseCoopers, 2016). The traditional financial reporting is increasingly supplemented by new reporting tools with qualitative and forward-looking information about business development (Rauschenberg, 2014). Public interest entities (PIEs) are obligated to report balance sheet, profit and loss statement, cash-flow statements, equity reconciliation and notes to the financial statements and in addition a management report. The management report must be in line with the financial statements and gives information about opportunities and risk, the outlook for the next 12 months and KPIs used (Rauschenberg, 2014). However, information requirements of stakeholders will no longer be adequately met with financials only (Müller, Stawinoga, \& Velte, 2015). Reporting like the integrated reporting (International Integrated Reporting Council, 2013) is focusing on future-oriented and stakeholder-oriented presentations of the internal and external influences on the value-added of companies (PricewaterhouseCoopers, 2012a). Part of the development of reporting is the new EU CSR directive (2014/95/EU 2014) which had the aim to harmonize and standardize the reporting on non-financials. Disclosing financial and non-financial information is now a regulatory requirement for defined undertakings within the EU. Thus, stakeholders will be informed over sustainability, CSR and non-financials and therefore the organizational performance instead of poor financial performance (Eccles \& Serafeim, 2013). PIE concerned by the EU directive should now at least report on environmental topics, social and employees matters, respect for human rights, anti-corruption and bribery.

The new EU directive is influencing the reporting of all companies, also the reporting of undertakings not in the scope of the directive. Small- and medium entities (SMEs) are also concerned.

\section{Development of Company Reporting}

For a long time, companies followed the shareholder value concept. Increasing the wealth of shareholders (owners) by paying dividends was the primary management goal. The company's success was only measured to the extent which it enriches shareholders and decisions were made focusing on improving short-term KPIs (Rappaport, 1999). Respectively, the organization and the company reports were focused on financial information (Rauschenberg, 2014). Information and KPIs included in company reports detailed the net assets, financial position and results of operations (e.g., cash flow, earnings, cost of capital, return on equity, earnings before interest and taxes). Financial statements are the sources of the main financial information and are meanwhile strictly regulated. Law and regulations for accounting, company reporting and obligatory disclosers get increasingly complex driven by the development of the business environment (e.g., hedging, sales of combined products or leasing), the fraudulent behavior (e.g., Ponzi, Enron), and nevertheless by the financial crisis. The accounting requirements are now stricter than ever, rules are very complex and a wide variety of notes have to be respected. 
As a second reporting line besides the obligatory financials, companies nowadays disclose perpetual information on sustainability and CSR. Depending on the EU member states, these reports were either voluntary or mandatory, the scope of items to be reported was limited or broad or either only state-owned companies were concerned or publicly-traded companies are also included (Szabó \& Sørensen, 2015). These reports were now published since years and were interpreted and discussed, but had the flaw of being a purely voluntary reporting (Bowen, 1953). Giving stakeholders additional information was without a legal obligation until the EU CSR directive (2014/95/EU 2014) was issued (Szabó \& Sørensen, 2015).

The future of company reporting can be seen in combining the two reporting lines and giving the stakeholders source of information (PricewaterhouseCoopers, 2012a). A first measure to combine the two reporting lines was the integration of non-financial information in management reports based on the EU Accounts Modernisation Directive 2003/51/EC (2003/51/EC 2003):

To the extent necessary for an understanding of the company's development, performance or position, the analysis shall include both financial and, where appropriate, non-financial key performance indicators relevant to the particular business, including information relating to environmental and employee matters.

The requirement was transformed in local laws of the EU member states, e.g., in Germany the Section 289 (3) for financial statements and Section 315 (1) Sentence 4 of the German Commercial Law (HGB) for consolidated accounts were added (Lanfermann, 2015). The law puts non-financial KPIs on par with financial KPIs in case they are material for understanding the business development. KPIs must be explained in the management report and reconciled to the financial statements (Müller et al., 2015).

Besides the Directive 2003/51/EC, various different approaches could be recognized in the EU supporting the reporting on non-financial information. For example, the United Kingdom focused on a single aspect of CSR with mandatory greenhouse gas emission reporting for quoted undertakings (Szabó \& Sørensen, 2015). France was the most progressive country regarding the CSR reporting as since 2001, French companies have to disclose a list of over 60 non-financial items. Since 2010, with the Grenelle II Act, the reporting requirement has been extended to all French limited companies based on a phase-in process until 2014 (Institut RSE Management, 2012).

The adoption of the EU Directive 2014/95/EU is an important step to a combined reporting as the report of non-financials is obligatory and the reporting is EU wide harmonized for companies in scope of the directive (2014/95/EU 2014):

Disclosure of non-financial information is vital for managing change towards a sustainable global economy by combining long-term profitability with social justice and environmental protection [...] Thus, the European Parliament called on the Commission to bring forward a legislative proposal on the disclosure of non-financial information by undertakings.

Disclosing non-financial information is not any more a voluntary initiative as the directive turns it into a regulatory requirement to help stakeholders to understand companies in the overall contribution to society (Ahern, 2016). Maximizing the shareholder value and report in that extent is not enough. Three considerations supported the directive. Firstly, the EU Commission assumes that shareholders and potential investors are "interested in social and environmental information" besides pure financial information. Secondly, non-financial information published by companies may not be balanced, as they may provide only positive aspects and neglect negative topics. Thus, mandatory standard reports should force companies to give a more 
objective view or insight. Thirdly, there is a need for comparability of information in the EU. A harmonized regulation in all EU member states results in a smaller cost impact on entities than establishing several different regulations (Szabó \& Sørensen, 2015).

According to the EU Directive, "large undertakings which are PIEs" with more than an average of 500 employees during the financial year are concerned by the new regulations (2014/95/EU 2014). PIEs include listed companies traded on a regulated market within the EU, credit institutions, insurance firms and also other entities defined as PIEs by EU member states. As an example, if a parent PIE operates in an EU member state, the consolidated financial statements had to report on the activity of the entire group (2014/95/EU 2014). Subsidiaries if included in the group reporting are exempted to report on their own. On the contrary, if the parent PIE operates outside the EU but with subsidiaries in EU member states, the logic of the directive would suggest that each subsidy should provide a single report.

\section{Increased Non-financial Reporting - Content and Discussion on the EU CSR Directive}

Based on the given scope of the directive, around 6,000 companies should be concerned (Voland, 2014). Taking into account the companies in relation to the ones that have to provide non-financial statements, like suppliers or subsidiaries which may also have to provide non-financial information in order to prepare the ultimate CSR corporate report, a lot more companies are finally concerned by the directive and will report standalone or the information will be included and published in the report of the parent company (Howitt, 2014). In the following, we outline the obligatory reporting topics of the EU Directive 2014/95/EU and discuss the directive.

The EU directive is obliging companies to provide at least information about "environmental, social and employee matters, respect for human rights, anti-corruption and bribery matters" (2014/95/EU 2014). According to the directive, the undertakings in scope should report the following on the defined topics to comply:

(1) A brief description of the company business model;

(2) A description of the policies pursued by the company in relation to those matters, including due diligence processes implemented;

(3) The outcome of those policies;

(4) The principal risks related to those matters linked to the company's operations including, where relevant and proportionate, its business relationships, products, or services which are likely to cause adverse impacts in those areas, and how these risks are managed;

(5) Non-financial KPIs.

The directive demands additional information on the reporting topics. Regarding environmental issues, details of the current and foreseeable impacts of the operations and, if "appropriate", on health and safety, the use of renewable and/or non-renewable energy, greenhouse gas emissions, water use and air pollution should be disclosed (2014/95/EU 2014). The information about social and employee-related issues may concern the actions taken to ensure gender equality, implementation of fundamental conventions of the International Labour Organisation, working conditions, social dialogue, respect for the right of workers to be informed and consulted, respect for trade union rights, health and safety at work and the dialogue with local communities, and/or the actions taken to ensure the protection and the development of those communities. Statement regarding human rights, anti-corruption and bribery could include information on the prevention of human rights abuses and/or 
on instruments in place to fight corruption and bribery. A description of the diversity policy applied in relation to the company's administrative, management and supervisory bodies with regard to aspects such as age, gender, or educational and professional backgrounds, the objectives of that diversity policy, how it has been implemented and the results in the reporting period can be also included (2014/95/EU 2014).

All of the topics have to be explained by the undertaking, so that in the case that one of the mandatory topics is not relevant the undertaking has to explain reasoned the fact that no information is provided. This comply-or-explain principle allows the undertaking to customize the reporting in the set scope and assures that the set standard topics are respected (Lanfermann, 2015; Voland, 2014).

Also in the case of a separate CSR report corresponding to the same financial year whether or not relying on national, EU-based or international frameworks (such as UN-Global Compact, OECD, ISO 26000, GRI, ILO, DNK, IIRC) and covering the information required for the non-financial statement, member states may also exempt companies from providing the non-financial statement, as long as it fulfils the requirements of the directive and is published no later than six months after the balance sheet date (2014/95/EU 2014). In exceptional cases, if the disclosure of information may be prejudicial to the commercial position of a company, member states may allow the omitting of information (2014/95/EU 2014). Thus, by risk on the commercial position of the undertaking, the entity can be exempted of a reporting or is allowed to omit information (Lanfermann, 2015).

In consequence, the impact of the directive on companies' processes is not as prejudicial as it could be expected. The scope of information to disclose is broad but companies have flexibility in the information to disclose as the directive does not request to report on precise issues but jut requests a general overview of companies' non-financial information in relation to their business. The directive gives a lot of flexibility to companies in the information to disclose as they can choose what to report as long as they cover the obligatory topics (2014/95/EU 2014). Besides, most large companies already provide information about CSR, either on their webpage or in specific reports (Stawinoga \& Velte, 2016). As the directive concerns mostly large companies, the requirement confirms from a regulatory perspective a current practice.

Finally, the noticeable change is the role of statutory auditors who will have to ensure the existence of the non-financial statement even if the examination of the report's content is actually not obliged by the directive (2014/95/EU 2014). The role of the statutory auditors is therefore limited (Lanfermann, 2015). On one hand, it is surprising that they should not review the content of the non-financial reports, but on the other hand, statutory auditors are qualified for certifying and giving an opinion on financial statements and not non-financial as these last ones are more related to qualitative rather than quantitative information (Szabó \& Sørensen, 2015). The directive leaves the decision of mandatory review and certification of the content to the member states. Article 225 of Grenelle II Act, 2010, in France already makes the certification by a third independent party compulsory for instance (Institut RSE Management, 2012).

The directive is accused for not going far enough in terms of requirement. Especially, the missing audit obligation for the additional information provided is seen as a weakness. Auditors are only obliged to confirm the existence of the non-financial reporting (Lanfermann, 2015). Finding the right balance between giving enough flexibility to companies to provide relevant information, cost aspects, and at the same time having enough comparable information between companies is difficult. Thus, the effort of the directive in harmonizing sustainability and social responsibility information within the EU should be acknowledged. 


\section{Development of KPIs to Non-financial Measurement}

Buying shares, to purchase a product or to sign a contract with a company is based on information given by companies. To measure the information, financial and non-financial KPIs are used. Indicators reported by companies in the past were pure financial and were helpful to analyze the financial situation like net asset position or cash flow. Non-financial KPIs, in addition, give the stakeholders important decision useful information. Reported non-financial KPIs differ from company to company and are specific to country, operation, and business. Below, some possible non-financial indicators are displayed based on the DANONE and BMW sustainable reports (see Table 1).

Table 1

Examples of General KPIs used in Sustainable Reports

\begin{tabular}{|c|c|}
\hline $\begin{array}{l}\text { General performance indicators for } \\
\text { environment }\end{array}$ & $\begin{array}{l}\text { 1. Primary energy consumption } \\
\text { 2. Share of renewable energies compared to total energy consumption } \\
\text { 3. Material consumption and recycling quota } \\
\text { 4. Water used and air bound emissions }\end{array}$ \\
\hline $\begin{array}{l}\text { General performance indicators for social and } \\
\text { employee concerns }\end{array}$ & $\begin{array}{l}\text { 1. Percentage of employees satisfied with their work } \\
\text { 2. Number of days of nonfatal injuries and illnesses } \\
\text { 3. Women as percentage of total employees } \\
\text { 4. Women in top-management - percentage (composition) of women as compared } \\
\text { to the total board members } \\
\text { 5. Number of hours volunteered by employees } \\
\text { 6. Significant collaborations with corporate partners, nonprofits, and } \\
\text { non-governmental organizations (NGOs) }\end{array}$ \\
\hline $\begin{array}{l}\text { General performance indicators for respect for } \\
\text { human rights }\end{array}$ & $\begin{array}{l}\text { 1. Percentage of staff with access to staff forum, grievance procedure or other } \\
\text { support } \\
\text { 2. Number of human rights policy assessments among workers } \\
\text { 3. Number and breakdown of code violations (e.g., unrespectful treatment, } \\
\text { discrimination, collective bargaining, employee relations, employee privacy, right } \\
\text { to organize, working hours) } \\
\text { 4. Percentage of staff that experienced harassment, discrimination, etc., as } \\
\text { expressed in employee surveyor channeled through external party (e.g., unions) }\end{array}$ \\
\hline $\begin{array}{l}\text { General performance indicators for } \\
\text { anti-corruption and bribery matters }\end{array}$ & $\begin{array}{l}\text { 1. Number of complaints received } \\
\text { 2. Nature of the received complaints (based on an established and applied rating) } \\
\text { 3. Number of disciplinary actions for corruption and bribery }\end{array}$ \\
\hline
\end{tabular}

For instance, listed companies like DANONE, operating in the food industry, are disclosing information related to sustainability and social responsibility with selected KPIs. In its 2014 Sustainability Report, DANONE uses the following indicators (DANONE, 2015) as shown in Table 2.

Table 2

Examples of Industry-Specific KPIs Used in Sustainable Reports

\begin{tabular}{|l|l|}
\hline \multirow{2}{*}{$\begin{array}{l}\text { Industry-specific performance indicators for } \\
\text { environment }\end{array}$} & $\begin{array}{l}\text { 1. Total water withdrawn from the surrounding area } \\
\text { 3. Final discharge of Chemical Oxygen Demand (COD) } \\
\text { 4. Net COD ratios (kg/metric ton of products) } \\
\text { 5. Total quantity of waste generated } \\
\text { 6. Total quantity of waste eliminated }\end{array}$ \\
\hline $\begin{array}{l}\text { Industry-specific performance indicators for } \\
\text { social and employee concerns }\end{array}$ & $\begin{array}{l}\text { 1. Total managers Female/Male of which directors and executives } \\
\text { 2. Average age female/male } \\
\text { 3. Total workforce of which international staff } \\
\text { 4. Total workforce of which local staff }\end{array}$ \\
\hline andistry-specific performance indicators for & Number of subsidies included in the mid-yearly reporting on internal fraud \\
\hline
\end{tabular}


Not all mandatory topics are reflected in the actual CSR reporting of DANONE or other companies as no KPIs are used to describe the human rights actions. Thus, changes to the disclosed information are expected not only for DANONE once the directive is enforced (DANAONE, 2015).

For SMEs, the following KPIs might be relevant depending on business and organization: (1) environment: cost of energy in percentage of total turnover. A rate above $4 \%$ qualifies for a production with high use of energy (Institut der Wirtschaftsprüfer, 2013); (2) social and employee concerns: number of days without any accident. Every accident at work should be avoided; and (3) anti-corruption and bribery matters: number of trainings given for employees to strengthen the awareness.

\section{Actual Situation and Impact on the Development of Companies Reporting}

Companies generally agree since a few years about the importance of providing non-financial information to increase the transparency especially regarding the social and environmental impact of corporate activities (Voland, 2014). In a study on corporate sustainability, authors from the Institute for Futures Studies and Technology Assessment already showed that in their sample of German companies, $80 \%$ said that sustainable development was relevant for them (Hahn \& Scheermesser, 2006). Since the study was conducted, the awareness to these topics increased. More companies understood the need of information by stakeholders and integrated non-financial information in their perpetual reports. In practice, the content of non-financial reporting differs from company to company.

A very appropriate classification of companies in respect to the attitude for sustainability and CSR is to divide between "sustainability leaders", "environmentalists", and "traditionalists" (Hahn \& Scheermesser, 2006).

Sustainability leaders are strongly committed into CSR topics, mainly motivated by ethical and moral factors and have already integrated CSR measures. The environmentalists, the majority of companies, the non-financial reporting are not ethical motivation. CSR policies are pursued because of ecological responsibility, image, or cost savings. Traditionalists acknowledge little relevance of CSR for their operations and thus implement few measures. They would commit to CSR for traditional business reasons, like opportunity of growth. Most of the traditionalists are SMEs. The study of Hahn and Scheermesser (2006) points out that a significant difference between the traditionalists and environmentalists is that the environmentalists are larger companies and have therefore more standardized management systems established like the European Foundation for Quality Management model (EFQM), Eco-Management and Audit Scheme (EMAS) or the standards from the International Organization for Standardization ISO standards 14000 and 9000 which enable a better control over the companies' operations on its environment, thus making the challenge of CSR easier to tackle.

Large public listed companies like the DAX 30 companies are the most advanced in the field of good corporate reporting and CSR as "almost all of the DAX 30 companies are providing sustainability reporting" (MAZARS, 2015). For example, the CSR Report of BMW, a DAX listed company, already disclosed information about environment, social issue, human rights, and anti-corruption topics (BMW, 2015). Smaller public-listed companies do not always publish CSR information as only $42 \%$ of the SDAX companies and only $33 \%$ of the TecDAX companies release information on CSR (MAZARS, 2015).

The impact of the new directive on undertakings differs. For large and public listed PIEs, the change will not be revolutionary as they are already disclosing such information, but the information provided will be harmonized and therefore better comparable. Some adjustments on the reporting may have to be done in order to comply with the format of the reporting, like adding new KPIs or developing topics especially human rights, anti-bribery or anti-corruption which were neglected in the past. 
Smaller listed PIEs which do not publish such reports in the past have to comply and amend their reporting processes to get the necessary information on non-financials. SMEs, even if they are not in the scope of the directive, might be included in the reporting processes as they have to provide CSR information to PIEs in the scope of the directive. SMEs as part of larger groups will align their reporting to the standards used by large PIEs. The aim to support stakeholders with one combined report is far not reached, but the trend goes from separated reporting silos over reporting with intersections to an integrated reporting.

The EU directive clearly indicates that, "SMEs should be exempted from additional requirements, and the obligation to disclose a non-financial statement should apply only to those large undertakings which are public-interest entities and to those public-interest entities which are parent undertakings of a large group" (2014/95/EU 2014). However, "this should not prevent member states from requiring disclosure of non-financial information from undertakings and groups other than undertakings which are subject to this Directive" (2014/95/EU 2014). Member states may require information from SMEs. SMEs related to PIEs may report CSR information as this information is needed to be included in the consolidated report of the parent company. Indeed, as it can be seen in CSR reports, the chain value can be mentioned and suppliers have thus to provide information (DANAONE, 2015). Thus, the EU directive will have an indirect impact on the reporting and processes of SMEs.

\section{The Future of Company Reporting - Combining Financials with Non-financial Information in One Report}

Company reports develop over time. Whether to invest or disinvest in a company is today judged by financials and also various non-financials (PricewaterhouseCoopers, 2016). Thus, stakeholders have an intense demand on reliable non-financial information.

The extended disclosure of non-financial information changed the way companies informed the public. Reported topics are now broad and cover a wide range of sustainability and CSR aspects (2014/95/EU 2014, 2003/51/EC 2003). The new EU Directive and the EU Accounts Modernisation Directive 2003/51/EC should increase the level of connection between non-financial and financial statements (Szabó \& Sørensen, 2015). Nevertheless, a high number of non-financial information are still separated and not reconcilable to the financial statements and are also not subject to an audit obligation (Lanfermann, 2015).

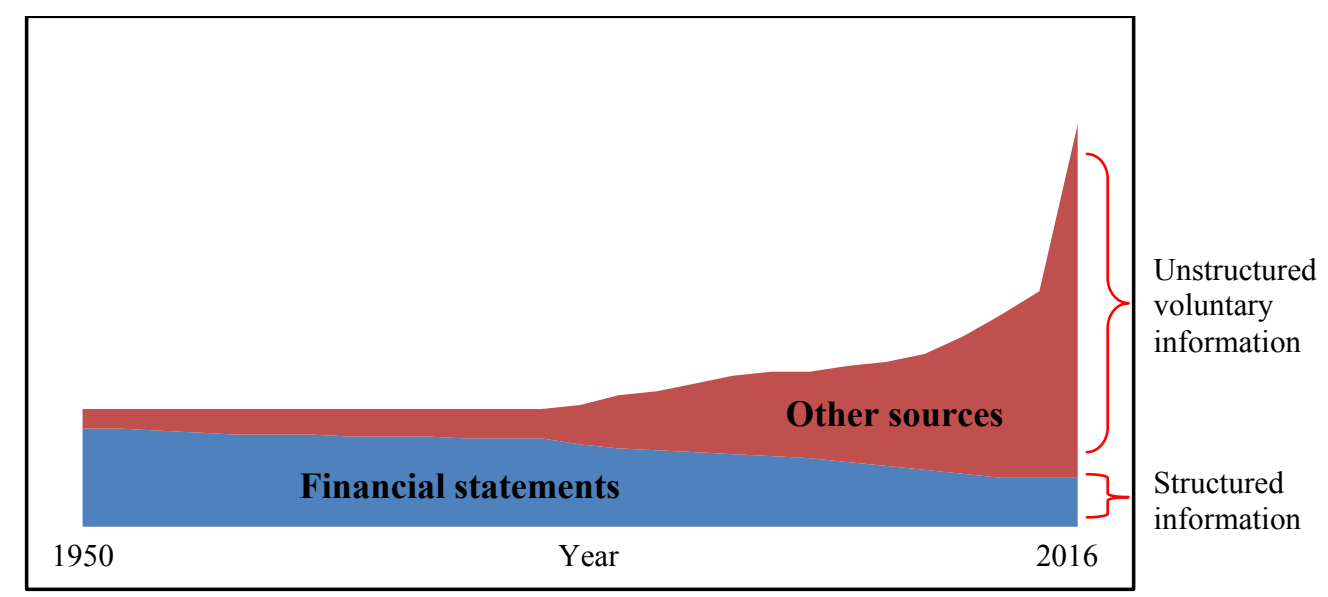

Figure 1. Increase in available information on companies. 
As displayed in Figure 1, due to the digitalisation and the possibility to get company information from different sources, the overall amount of unstructured information about companies increased over time, while the amount of financial information is nearly stable. Audit reports tend to be leaner and more focused including an increased number of notes. For the future of company reporting, an integrated reporting should be envisaged, thus the complete demand of stakeholders could be fulfilled with one report. Thus reports, structure all decision useful information in one report for the stakeholders and the reliability could be increased by an audit obligation. Main focus of such integrated reporting should be to inform stakeholders about the possibilities of companies to create value over time (Serafeim, 2015; PricewaterhouseCoopers, 2012b). One organisation promoting the integrated reporting is the International Integrated Reporting Council (IIRC). The IIRC fosters the communication about value creation as the next step in the evolution of corporate reporting (Integrated Reporting, 2015).

\section{Conclusion}

Corporate reporting contents develop over time due to changes in law, regulations, technology, the development of the economy, and the demand for information by stakeholders. The shareholder value concept was for a long time the dominant organization approach that influenced the information to stakeholders (Rappaport, 1999). With the digitalization, the amount of available information increased and the process of investment decision changed. As the society and the perception of the economy are changing, company reports need to fulfill the increased demand of stakeholders on non-financials as also more non-financials were taken into account by making investments. Given information to stakeholders are often separated in at least two reports, so that financial statements and non-financial reports like CSR are disconnected and not reconcilable. One interface between the reporting lines is based on the EU Accounts Modernization Directive 2003/51/EC (2003/51/EC 2003) which raised the obligation to include non-financial KPI's in management reports. Another very important development in company reporting is the new EU directive 2014/95/EU (CSR Directive) which is enforced in 2017. The CSR Directive is increasing the binding character of non-financial as the directive requests a harmonized reporting within the EU for dedicated companies. The directive develops sustainability and CSR reporting as it turns, what has been so far voluntary and not easy comparable, into a standardized obligation. The future of company reporting is the combined reporting of financials and non-financials as only such a reporting can fulfill the demand of information by stakeholder.

\section{References}

Ahern, D. (2016). Turning up the heat? EU sustainability goals and the role of reporting under the non-financial reporting directive, European Company and Financial Law Review, 13(4), 599-630.

BMW. (2015). Sustainable value report $2014 . \quad$ Retrieved from https://www.bmwgroup.com/content/dam/bmw-group-websites/bmwgroup_com/responsibility/downloads/en/2014/BMW_G roup_SVR2014_EN.pdf

Bowen, H. R. (1953). Social responsibilities of the businessman. New York, NY: Harper \& Brothers.

DANONE. (2015). DANONE 14 sustainable report. Strategy and performance - Bringing health through food to as many people as possible. Retrieved from http://danone.at/wp-content/uploads/Danone_Sustainability_Report_2014.pdf

Directive 2003/51/EC of the European Parliament and of the Council of 18 June 2003 amending Directives 78/660/EEC 83/349/EEC and 86/635/EEC and 91/674/EEC and other financial institutions and insurance undertakings.

Directive 2013/34/EU of the European Parliament and the Council of 26 June 2013 on the annual financial statements, consolidated financial statements and related reports of certain types of undertakings, amending Directive 2006/43/EC of the European Parliament and of the Council and repealing Council Directives 78/660/EEC and 83/349/EEC. 
Directive 2014/95/EU of the European Parliament and the Council of 22 October 2014 amending Directive 2013/34/EU as regards disclosure of non-financial and diversity information by certain large undertakings and groups.

Eccles, R. G., \& Serafeim, G. (2013). The performance frontier: Innovating for a sustainable strategy. Harvard Business Review, 91(5), 50-60.

Hahn, T., \& Scheermesser, M. (2006). Approaches to corporate sustainability among German companies. Corporate Social Responsibility and Environmental Management, 13(3), 150-165.

Howitt, R. (2014). The time is now for company non-financial reporting. Retrieved from http://www.euractiv.com/section/sustainable-dev/opinion/the-time-is-now-for-company-non-financial-reporting/

Institut der Wirtschaftsprüfer. (2013). IDW Prüfungstandard: Prüfung nach dem Kraft-Wärme-Kopplungsgesetz (pp. 1-62).

Institut RSE Management. (2012). Survey No. 7. The Grenelle II Act in France: A milestone towards integrated reporting.

Integrated Reporting. (2015). Creating value - Integrated reporting (IR) and investor relation. December 2015.

International Integrated Reporting Council. (2013). International $<I R>$ framework. December 2013.

Lanfermann, G.(2015). EU-Richtlinie zur Angabe von nichtfinanziellen Informationen. WPg: Kompetenz schafft Vertrauen, 68(7), 322-326.

MAZARS. (2015). How public companies are dealing with the upcoming CSR reporting requirements. Retrieved from http://eng.mazars.de/Home/Our-expertise/Impulse/Content/CSR-Reporting

Müller, S., Stawinoga, M., \& Velte, P. (2015). Mögliche Einbettung der neuen nichtfinanziellen Erklärung in die handelsrechtliche Unternehmenspublizität und -prüfung: Erkenntnisse aus den Stellungnahmen zum Konzeptpapier des BMJV zur nationalen Umsetzung der CSR-Richtlinie. Der Betrieb, 68, 2217-2223.

PricewaterhouseCoopers. (2012a). Integrated reporting - The future of corporate reporting.

PricewaterhouseCoopers. (2012b). Auf dem Weg zum Integrated Reporting.

PricewaterhouseCoopers. (2016). It's not just about the financials - The widening variety of factors used in investment decision making.

Rappaport, A. (1999). Shareholder value. Stuttgart: Schäffer-Poeschel Verlag.

Rauschenberg, F. (2014). Die Prüfung nichtfinanzieller Informationen im Konzernlagebericht vor dem Hintergrund der regulatorischen Änderungen und der Haftung des Wirtschaftsprüfer, Der Konzern, 9/2014, Frankfurt am Main, pp. $319-323$.

Serafeim, G. (2015). Integrated reporting and investor clientele. Journal of Applied Corporate Finance, 27(2), 34-51.

Stawinoga, M., \& Velte, P. (2016). Der Referentenentwurf für ein CSR-Richtlinie-Umsetzungsgesetz (pp. 841-847). Der Betrieb.

Szabó, D. G., \& Sørensen, K. E. (2015), New EU directive on the disclosure of non-financial information (CSR). ECFR, pp. 307-340.

Voland, T. (2014). Erweiterung der Berichtspflichten für Unternehmen nach der CSR-Richtlinie. Der Betrieb No. 49, pp. 2815-2818. 